\title{
Przemysław Osóbka
}

$\mathrm{PhD}$, Kujawy and Pomorze University in Bydgoszcz, Institute of Law, https://orcid.org/0000-0003-4632-840X

\section{CLIMATE CHANGE AND THE CONVENTION RELATING TO THE STATUS OF REFUGEES OF 28 JULY 1951}

Abstract: The article deals with The United Nations Convention relating to the Status of Refugees, Geneva, 28.7.1951 in the context of climate change consequences. Refuge is strictly defined category in the acts of international law. It does not include environmental and climatic reasons to leave one's country of origin. However, in 1990, the Intergovernmental Panel on Climate Change (IPCC) drew attention to the fact that human migration could be one of the greatest effects of climate change.

The author also analyzes the meaning of the provisions of Article 3 and Article 8 ECHR in the discussed area. The article tries to give an answer to the question whether and why it is necessary to apply the Geneva Convention to climate change refugees if they can be protected under core human rights treaties. It is of greatest interest to the extent where if refers to the climate change refugees situation in New Zeeland and Australia. These states seem to be pioneers in giving refugees protection due to climate change consequences.

Probably adaptation of the 1951 Convention to the challenges facing the international community in connection with climate change will in itself become an expression of its responsibility for the consequences of these changes and their impact on individuals and entire communities. 
Keywords: refugees, migration, climate change, environment, responsibility, the 1951 Convention

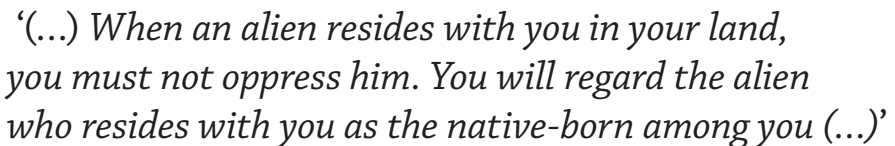

Leviticus 19:33-34

\section{Introduction}

The United Nations Convention relating to the Status of Refugees, Geneva, 28.7.1951 ${ }^{1}$ is a key international law document on the protection of refugees. It defines who is a refugee, what are the rights of refugees, and what are the obligations of host countries. The 1951 Convention was accompanied by the Protocol relating to the Status of Refugees, New York, 31.1.1967, which abolished time and geographical constraints in granting refugee status. ${ }^{2}$

'Refugee' is a category strictly defined in the acts of international law. It does not include, among others forced internal migrants, as well as persons forced to leave their country of origin in connection with reasons other than those referred to in the 1951 Convention. ${ }^{3}$

Article 1 of Convention relating to the Status of Refugees define refugee as a person who:

(...) is outside the country of his nationality and is unable or, owing to such fear, is unwilling to avail himself of the protection of that country; or who, not having a nationality and being outside the country of his former habitual residence as a result of such events, is unable or, owing to such fear, is unwilling to return to it (...).

Increasingly, however, there are voices suggesting the need to extend the scope of application of the Convention to new groups in need of protection. These include, for example, people displaced due to natural

1 Convention relating to the Status of Refugees, Geneva, 28.7.1951, United Nations Treaty Series, vol. 189, p. 137.

2 Protocol relating to the Status of Refugees, New York, 31.1.1967, United Nations Treaty Series, vol. 606, p. 267.

3 B. Termiński, Migracje, uchodźstwo i wysiedlenia wewnętrzne w świecie doby globalizacji: studium socjologiczno-prawne [Refugee and Internal Displacement in the World of Globalisation: Sociological and Legal Studies], Regensburg 2016, p. 137. 
disasters and the consequences of climate change. The Office of the United Nations High Commissioner for Refugees (UNHCR) has repeatedly expressed the opinion that the use of the term 'climate refugee' has no basis in international law on refugees and, what is more, it may potentially violate the applicable legal status. ${ }^{4}$

Already in 1990, the Intergovernmental Panel on Climate Change (IPCC) drew attention to the fact that human migration could be one of the greatest effects of climate change. ${ }^{5}$

In 2009 UNHCR acknowledged that environmental factors can contribute to the induction of cross-border migration flows, but it still believes that these are not a sufficient reasons to grant refugee status under the Convention on the Status of Refugees. ${ }^{6}$

Almost ten years later, publishing its recommendations for the climate summit in Katowice (COP24) UNHCR again drew attention to the need for further analysis and guidance on the applicability of refugee law in the context of climate change and disasters. ${ }^{7}$

Consequently, migration still looks like an adaptation and survival strategy of populations experienced by the negative effects of climate change. And yet the international community have no international legal instruments that specifically and explicitly define environmental (climate) migration or climate (environmental) migrants (refugees). ${ }^{8}$

It seems that nowadays the controversy does not raise the view that climate change is the driving force of migration, in which people are forced to leave their homes. Regardless of whether we want to consider migration as an adaptation strategy or an element of a planned relocation, climate

4 W. Kälin, N. Schrepfer, Protecting People Crossing Borders in the Context of Climate Change: Normative Gaps and Possible Approaches, UNHCR, Geneva 2012, p. 28.

5 Intergovernmental Panel on Climate Change (IPCC), Climate change. The IPCC Impacts Assessment, 1990, p. 5-9, https://www.ipcc.ch/site/assets/uploads/2018/03/ ipcc_far_wg_II_full_report.pdf (accessed 14.2.2019).

6 Climate change, natural disasters and human displacement: a UNHCR perspective, UNHCR Policy Papers, 2009, p. 9, http://www.unhcr.org/protection/ environment/4901e81a4/unhcr-policy-paper-climate-change-natural-disasters-humandisplacement.html (accessed 14.2.2019).

7 Climate change and disaster displacement: Key Messages on international protection COP 24 - Katowice, Poland, 3 to 14.12.2018, https://www.unhcr.org/ protection/environment/5c0172f24/key-messages-for-cop24.html (accessed 14.2.2019).

8 M.K. Solomon, K. Warner, Protection of Persons Displaced as Results of Climate Change. Existing Tools and Emerging Frameworks, [in:] M.B. Gerrard, G.E. Warnier (ed.), 'Threatened Island Nations', Cambridge University Press 2013, pp. 243-245. 
change also acts as a 'threat multiplier' that exacerbates conflicts due to dwindling natural resources.

It gives rise to considerations about the meaning of the 1951 Convention in the modern world. A very important stance in this debate is taken by Professor Jane McAdam, who claims that there are at least seven reasons why this assumption about the need to radically change the Convention is wrong. One of the arguments she uses indicates that, like any treaty, the Convention must not only be implemented, but enforced to have any meaning. Already more than 140 countries have signed the 1951 Convention and yet there are now more refugees in the world than before the Second World War. It seems, therefore, that the problem is not the lack of law, but the lack of will to implement it. ${ }^{9}$

Strong emotions, which are often increased by media messages about the influx of refugees and migrants to Europe, are not conducive to the search for a good solution to this situation. There is a high risk that societies will begin to lose sensitivity to the needs of people who have to face the real risks of loss of life, health, property or the sources of livelihood for themselves and their relatives.

Many authors and sources indicate that the term environmental refugee was used for the first time by Essam El-Hinnawi in a 1985 UN Environment Program publication. ${ }^{10}$

Today, more than thirty years have elapsed since the publication of El-Hinnawi's paper, but debate is more active than ever about linking the environment with refugees. The Marrakech Intergovernmental Conference to Adopt the Global Compact for Safe, Orderly and Regular Migration (10-11.12.2018, Marrakech) adopted a draft document which states that migration movements may be the result of sudden-onset and slow-onset natural disasters, the adverse effects of climate change, and environmental degradation as well as other precarious situations. These arguments were

9 J. McAdam, Climate Change, Forced Migration, and International Law, OxfordNew York 2012, pp. 42-48; J. McAdam, Seven reasons the UN Refugee Convention should not include 'climate refugees', 'The Sydney Morning Herald', 6.6.2017, https://www.smh. com.au/opinion/seven-reasons-the-un-refugee-convention-should-not-include-climaterefugees-20170606-gwl8b4.html (accessed 14.2.2019).

10 E. El-Hinnawi, Environmental Refugees, United Nations Environment Programme, Nairobi 1985, http://hdl.handle.net/20.500.11822/2651 (accessed 15.2.2019). 
recognized by the Intergovernmental Conference in the 2018 global compact on safe, orderly, and regular migration under its Objective Two. ${ }^{11}$

It is worth noting that the European Union is also boldly beginning to recognize the problem of climate refugees. Taking up discussions on this subject, the EU refers directly to the output derived from the trend initiated by El-Hinnawi. ${ }^{12}$

I think that these are sufficient reasons to reflect on the impact that climate change exerts and will exert on the international legal regime concerning refugees. It seems that it is all the more necessary because the 1951 Convention leaves people forced to migrate for climatic or environmental reasons outside the scope of the support offered. I hope that the article will satisfy the expectations and intellectual needs of readers in this regard.

\section{The 1951 Refugee Convention and climate change - various aspects}

The Convention Relating to the Status of Refugees and the States applying it in practice are nowadays facing absolutely unprecedented challenges and the test of time. Over the course of preceding decades, however, given the number of arguments to extend the regime of the Convention, it sometimes seems that a significant portion of the specialists in the field of international law and in particular humanitarian law evidence a large distance from, and even reluctance to confront, the issue of 'climate refugees'. It involves in particular an a priori refusal to consider whether the appropriate legal solutions, providing protection for the population at risk, can be sought on the basis of international humanitarian law, insofar as no other branch of international law seemed appropriate to take up this challenge. Thus, the issue remains ignored in international law. ${ }^{13}$

11 Intergovernmental Conference to Adopt the Global Compact for Safe, Orderly and Regular Migration, Marrakech, Morocco, 10 and 11.12.2018, A/CONF.231/3, p. 9/31.

12 J. Apap, The concept of 'climate refugee', Towards a possible definition, European Parliamentary Research Service, February 2019, http://www.europarl.europa.eu/ thinktank/en/document.html?reference=EPRS_BRI(201 8)621893 (accessed 15.2.2019).

13 P. Osóbka, The Problem of 'Climate Refugees' in the Perspective of International Humanitarian Law-Selected Issues, [in:] 'Studia z zakresu nauk prawnoustrojowych. Miscellanea', vol. 2, no. VIII, Bydgoszcz 2018. 
The reasons for which refugee status is granted today on the basis of the 1951 Convention are limited to a minimum. The basis for granting asylum in the current legal status is a statement of individual persecution due to race, religion, nationality, membership in a particular social group or because of political beliefs. For people crossing international boundaries, the specific protections afforded under the 1951 Refugee Convention are limited to refugees fleeing persecution, and as such the terms of the Convention exclude any of other factors, including especially climate change and environmental degradation. ${ }^{14}$

Criticism about the concept of recognition of 'environmental refugees' was expressed, for example, by Richard Black ${ }^{15}$ and Etienne Piguet. ${ }^{16}$ On the other hand, it is worth recalling the great complexity of the causes of environmental migrations which, Franklin Cardy pointed out, including extreme natural disasters and industrial accidents, resettlement for development purposes (eg. construction of water reservoirs) and malnutrition and poor health of some populations, which may result from the lack of sufficient food resources, the use of degraded land and contaminated drinking water sources or even a total lack of access to them. ${ }^{17}$

Of course, the various aspects of the definition of 'refugee' don't meet the definition of people displaced because of climate change effects. But, we cannot definitively state that it cannot be applied; however, this manner of application is very rare. ${ }^{18}$

An extremely important element in the definition of a refugee is the fact of being persecuted or the threat of persecution as the basis for a justified fear. According to UNHCR, there is no universally accepted definition of persecution. UNHCR Guidelines for Article 33 of the 1951 Convention stipulate that persecution becomes a threat to life or freedom based on race, religion, nationality, political beliefs or membership in a

14 S.O. Stapleton, R. Nadin, Ch. Watson, J. Kellett, Climate change, migration and displacement: the need for a risk-informed and coherent approach, Overseas Development Institute and United Nations Development Programme 2017, p. 27.

15 R. Black, Environmental refugees: myth or reality?, New Issues in Refugee Research, Working Paper No. 34, UNHCR 2001, p. 1.

16 E. Piguet, Climate change and forced migration, New Issues in Refugee Research, Working Paper No. 153, UNHCR 2008, p. 8

17 F. Cardy, Environment and forced migration. A review, Nairobi 1994, p. 2-3.

18 J. McAdam, Climate Change-related Displacement of Persons, [in:] 'The Oxford Handbook of International Climate Change', Oxford University Press 2016, p. 522. 
particular social group. At the same time, UNHCR recognizes that other serious violations of human rights may also constitute persecution. ${ }^{19}$

The meaning of persecution in this context is not applicable in common to people displaced for reasons related to the environment. It would be probably very difficult to consider environmental damages and degradation as persecution in the sense in which it is used in the 1951 Convention. Finally, it would also be necessary to find linkage between persecution and one of the elements set out in the Convention. ${ }^{20}$

Interesting conclusions in this regard are drawn also by Robert Brears, who points out that in the absence of a fixed definition of the word persecution, it can be postulated that it also includes violations of economic, social, political and even environmental laws. ${ }^{21}$

Probably it would be easier to agree with this idea if we would accept that climate change jeopardizes at least three key human rights: right to life, right to health, and right to subsistence. Of course, it doesn't mean that other rights are secure. ${ }^{22}$

By which is meant, for example, the right to clean and healthy environment. Even if discrepancy can be observed between some universal international documents, we should bear in mind a lot of regional regulations that recognize implicit right. Provisions mentioning the Stockholm Declaration $^{23}$ and the Rio Declaration ${ }^{24}$ could seem to be controversial in the human rights context, and they are not always coherent. ${ }^{25}$

19 UNHCR, Handbook on Procedures and Criteria for Determining Refugee Status under the 1951 Convention and the 1967 Protocol relating to the Status of Refugees, HCR/IP/4/Eng/ REV.1 Reedited, Geneva, January 1992, point 51.

20 J. Apap, op. cit.

21 R. Brears, Environmental Refugees from the Maldives: Are They Protected?, 25.7.2009; https://ssrn.com/abstract=1438822 (accessed 16.2.2019).

22 S. Caney, Climate change, human rights and moral thresholds, [in:] S. Humphreys (ed.) 'Human Rights and Climate Change', Cambridge University Press 2010, p. 75.

23 Declaration of The United Nations Conference on the Human Environment, Stockholm 1972, [in:] 'Report of the United Nations Conference on the Human Environment', UN Doc.A/CONF.48/14/Rev.1.

24 Rio Declaration on Environment and Development, 1992, A/CONF.151/26.

25 Despite these controversies it cannot be omitted that as the consequence of the Rio Declaration UNECE Convention on Access to Information, Public Participation in Decision-making and Access to Justice in Environmental Matters (Aarhus Convention) was adopted on 25.6.1998, see http://www.unece.org/fileadmin/DAM/env/pp/documents/ cep43e.pdf (accessed 20.3.2019). 
But, it is generally accepted that environmental concerns are expressed in terms of a human right to clean or healthy environment, that substantive human rights may be threatened by environmental degradation, and that procedural human rights (for example freedom of association) are important in the realization of environmental goals. ${ }^{26}$

The right to a clean environment belongs to the third generation of human rights. There are some good examples of approaches to these problems in regional human rights instruments and in the jurisprudence of international tribunals and courts.

According to Article 24 of the African Charter on Human and Peoples' Rights adopted on 27.6.1981 all peoples shall have the right to a general satisfactory environment favorable to their development. ${ }^{27}$ Article 11 of Additional Protocol to the American Convention on Human Rights in the Area of Economic, Social and Cultural Rights guarantees that everyone shall have the right to live in a healthy environment. Furthermore, States Parties shall promote the protection, preservation, and improvement of the environment. ${ }^{28}$ ASEAN (Association of South East Asian Nations) Human Rights Declaration in Article 28 states that every person has right to an adequate standard of living for himself or herself and his or her family, including the right to a safe, clean, and sustainable environment. In Article 35 ASEAN Declaration states also that the right to development should be fulfilled so as to meet equitably the developmental and environmental needs of present and future generations. ${ }^{29}$ The Arab Charter on Human Rights includes only the following general remark in its Article 30: 'The State guarantees every citizen's right to work in order to secure for himself a standard of living that meets the basic requirements of life." ${ }^{30}$

The European perspective of seeking a solution to these problems differs significantly from that found in countries exposed to the direct impact of the negative effects of climate change. There are no explicit provisions regarding the protection of this right in the European Convention

26 E. Hey, Advanced Introduction to International Environmental Law, Elgar Publishing 2016, p. 124.

27 African Charter on Human and Peoples' Rights, 27.6.1981, OAU Doc. CAB/ LEG/67/3 rev. 5, 21 I.L.M. 58 (1982).

28 Additional Protocol to the American Convention on Human Rights in the Area of Economic, Social and Cultural Rights 'Protocol of San Salvador', 17.11.1988 (A-52).

29 ASEAN Human Rights Declaration and Phnom Penh Statement on the Adoption of the ASEAN Human Rights Declaration, ASEAN Secretariat, Jakarta, February 2013.

30 Arab Charter on Human Rights adopted in Cairo on 15.9.1994. 
on Human Rights ${ }^{31}$, because in the era when this document was crafted, interest in environmental protection and the recognition of its impact on life, health and well-being of people did not have, in Europe, the importance it possesses today. Nevertheless, the European Court of Human Rights sometimes undertakes effective protection by resolving cases concerning environmental protection mainly based on Article 8 ECHR. ${ }^{32}$

Article 8 ECHR has been relied on in various cases involving environmental concern, yet it is not violated every time that environmental deterioration occurs: no right to nature preservation as such is included among the rights and freedoms guaranteed by the Convention. In order to raise an issue under Article 8 ECHR the interference must directly affect the basic requirements of the applicant's life, home, family, or private life. ${ }^{33}$

It is also possible that the European Court of Human Rights will adopt a decision similar to that of the UN Human Rights Committee and engage European states non-refoulement obligations, under Article 2 or Article 3 ECHR, when individuals face removal to their home countries where they risk life-threatening conditions due to climate change. ${ }^{34}$ It is possible that under certain circumstances returning a person who has been displaced due to climate change could amount to inhuman or degrading treatment in violation of non-refoulement provisions in the meaning of Article $3 \mathrm{ECHR}{ }^{35}$

Not everyone is so enthusiastic about the applicability of Article 3 ECHR in this regard. Professor Jane McAdam said that the chance of a complementary protection mechanism based on Article 3 ECHR becoming a meaningful protection mechanism is slim. She argues that it will only

31 Convention for the Protection of Human Rights and Fundamental Freedoms, Rome, 4.11.1950.

32 See i.e.: Case of Di Sarno and Other v. Italy, Application no. 30765/08, Judgement of 10.1.2012, paras. 94-96; Case of Guerra and Others v. Italy, Application no. 14967/89, Judgement of 19.2.1998, paras. 56-60; Case of Dzemyuk v. Ukraine, Application no. 42488/02, Judgement of 4.9.2014, para. 92; Case of Hardy and Maile v. The United Kingdom, Application no. 31965/07, Judgement of 14.2.2012, paras. 183-192.

33 See i.e.: Fadeyeva v. Russia, Application no. 55723/00, Judgement of 9.6.2005, para. 68; Kyrtatos v. Greece, Application no. 41666/98, Judgement of 22.5.2003, para. 52.

34 E. Delval, From the U.N. Human Rights Committee to European Courts: Which protection for climate-induced displaced persons under European Law?, http://eumigrationlawblog. eu/from-the-u-n-human-rights-committee-to-european-courts-which-protection-forclimate-induced-displaced-persons-under-european-law/ (accessed 30.5.2020).

35 J. Verschuuren, Research Handbook on Climate Change Adaptation Law, Elgar Publishing 2013, p. 97. 
be under the most exceptional circumstances that a lack of resources will be found to be a reason prohibiting forced return. ${ }^{36}$

The situation has changed significantly in the face of the migration crisis that has affected the European Union. But, the extreme emotions which often accompany media reports on the inflow of refugees from Africa, Asia and Middle East to Europe, serve to erode the sensitivity customarily felt by the European community to the needs of people who are forced to face the risk of losing their or their loved one's life, property, workplace, or education.

This way of thinking may arouse astonishment because it seems to be impossible not to notice that the natural disasters resulting from climate change are the source of many migrations in the $21^{\text {st }}$ century. In 2006-2010 Syria suffered the largest drought in forty years. The effects of climate change in Syria were already evident from the cycles of drought, which have shortened from a cycle of fifty-five years in the past to the contemporary cycle of seven to eight years. ${ }^{37}$

As a result of the drought in Syrian, harvests of wheat, cotton and barley were reduced by fifty percent, ${ }^{38}$ and barren grazing pastures together with a seventy-five percent rise in animal feed costs have led to the loss of over eighty percent of the livestock belonging to small- and medium-scale herders; ${ }^{39}$ nearly seventy-five percent of these households suffered total crop failure ${ }^{40}$ and up to as many as two million Syrians were displaced by the drought. ${ }^{41}$

36 J. McAdam, The European Union Qualification Directive: The Creation of a Subsidiary Protection Regime, 'International Journal of Refugee Law' 2005, vol. 17, no. 3, pp. 461-516.

37 Report of the Special Rapporteur on the right to food, Olivier De Shutter. Mission to the Syrian Arab Republic, A/HRC/16/49/Add.2, http://www2.ohchr.org/english/bodies/ hrcouncil/docs/16session/A.HRC.16.49. Add.2_en.pdf (accessed 4.03.2019).

38 Environmental Justice Foundation (EJF), Beyond Borders: Our changing climate its role in conflict and displacement, EJF 2017, p. 34, https://ejfoundation.org/resources/ downloads/BeyondBorders.pdf (accessed 4.3.2019).

39 FAO's role in the Syria Drought Response Plan, 11.8.2009, http:/www.fao.org/ fileadmin/user_upload/emergencies/docs/app_syriadrought2009.pdf (accessed 4.3.2019).

40 Arab Center for the Studies of Arid Zones and Dry Lands, United Nations, Secretariat of the International Strategy for Disaster Reduction, Drought vulnerability in the Arab region. Case Study - Drought in Syria. Ten Years of Scarce Water (2000-2010), Damascus April 2011, p. 26, https://www.unisdr.org/files/23905_droughtsyriasmall. pdf (accessed 4.3.2019).

41 J. Selby, O.S. Dahl, Ch. Fröhlich, M. Hulme, Climate change and the Syrian civil war revisited, 'Political Geography' 2017, vol. 60, p. 237. 
I don't think that drought or man-made climate change effects were the direct causes of the civil war in Syria. But it cannot be failed to notice that about one and one-half million people moved from villages to cities and camps near Syria's major cities of Aleppo, Damascus, Dara'a, Deir ezZour, Hama, and Homs, and one of the earliest manifestations of unrest began around the town of Dara'a, which saw a really large influx of farmers and unemployed young men displaced off their lands by crop failures. ${ }^{42}$

The migration crisis caused by among others the civil war in Syria and the associated influx of refugees from Africa, Asia and the Middle East, which Europe has been facing since 2015, means that both the Court of Justice of the European Union and the European Court of Human Rights must now confront their case law with an attempt to redefine the concept of 'refugee', whose current use is based on the 1951 Convention.

Not only does climate change contribute to outbreaks of armed conflict, but military action alone can cause irreversible changes in the environment. This is clearly seen in the discussed example of Syria. As Bradley Cummings wrote, fighting near to the main crop cultivation centers close to Aleppo has also led to increasingly barren terrain. Crop production in these areas decreased due to lack of power, increased fuel costs, and damage to irrigation systems. ${ }^{43}$

\section{Possibilities of applying the 1951 Convention for the protection of environmental or climate refugees}

The legal objections question the term 'environmental refugee' in two ways. The 1951 Convention legally defined a 'refugee', and people displaced by environmental causes do not qualify under its conditions. Anthony OliverSmith aptly noticed that applying the term 'refugee' to environmentally displaced people could mask the true causes of displacement and allow states to evade their obligation to provide asylum. ${ }^{44}$

42 P.H. Gleick, Water, Drought, Climate Change, and Conflict in Syria, 'Weather, Climate, and Society' 2014, vol. 6, no. 3, p. 334-335.

43 B. Cummings, Refugees of the 21st Century: Climate Change and an Uninhabitable Middle East/North Africa, 'University of Denver Water Law Review' 2019, vol. 22, no. 2, p. 745-777.

44 A. Oliver-Smith, Debating Environmental Migration: Society, Nature and Population Displacement in Climate Change, 'Journal of International Development' 2012, vol. 24, pp. 1061-1062. 
Constructive criticism is extremely important in this respect because it shows the weaknesses of the concept of 'environmental refugee' as well 'climate refugee'.

According to Betsy Hartmann the 'environmental refugee' concept has a number of shortcomings. First, it is depoliticizing because it naturalizes the economic and political causes of environmental degradation and masks the role of institutional responses to it. Second, the concept of environmental refugee may be dehistoricizing, thereby eliding the causes of why particular populations are more vulnerable than others and placing the blame on nature rather than on social, economic or political causes. Thirdly, Hartmann says the concept of 'environmental refugee' overemphasizes the role of demographic pressures in migration. ${ }^{45}$

Still other researchers harbor political objections to the concept of 'environmental refugee' because of the fear of climate-induced migration that has entered European and North American political discourse in last years.

Regardless of whether I agree with the above views or not, I cannot fail to notice that there are some significant difficulties in qualifying environmentally displaced persons as refugees under international law.

They may be due to the fact that the concept of a refugee assumes a special responsibility of society: a refugee, fleeing from his country, seeking help in other countries, and even in the whole international community. Therefore, the refugee becomes the responsibility of the entire international community. This is an expression of the collective responsibility of the international community in implementing and respecting human rights throughout the world. ${ }^{46}$

The requirement of a causal connection between the state of being persecuted and a ground of protection offered by the 1951 Convention is a core of this act, but it also seems that the issue of different motivations for migration may become important. Probably the grounds established by the 1951 Convention need not be shown to be the sole, or even a dominant,

B. Hartmann, Climate Refugees and Climate Conflict: Who's Taking the Heat for Global Warming?, Paper delivered at the panel on Climate Change, 2007, 4S Annual Conference Montreal, Quebec, 11.10.2007, http://www.disasterdiplomacy.org/pb/hartmann2008. pdf (accessed 22.3.2019).

46 V. Magniny, Les réfugiés de l'environnement : hypothèse juridique à propos d'une menace écologique, Thèse pour le doctorat en droit présentée et soutenue publiquement le 25 Mai 1999, Paris 1999, pp. 55-56. 
cause of the risk of being persecuted. It needs only to be a contributing factor to the risk of being persecuted. ${ }^{47}$

Finally, there are possible cases for refugee protection in situations where harmful action or inaction by a Government in dealing with climate related events are related to one or more of the 1951 Convention contexts (such as denial of humanitarian assistance to a minority group) and could, as a result, be considered persecution. ${ }^{48}$ There may be also found some limited situations where individual situations will comply with the 1951 Convention definition. For example, it can be easily imagined if good land for farming or grazing becomes scarce and one group forces another off the land and the State is unable to prevent it. ${ }^{49}$

A lot of new content to the issue affords the assumption that 'climate refugee' may be covered not only by the 1951 Convention but also by broader protection obligations imposed on states that stem from Article 7 of the International Covenant on Civil and Political Rights. ${ }^{50}$ This is an example of the limited number of rights in international human rights instruments and customary law that supplement the 1951 Convention. Article 7 of ICCPR imposes a broader protection obligation on states, which may be described as complementary protection. ${ }^{51}$

There are no doubts that the definition of degrading treatment is evolving not only in human rights instruments but also in the national jurisprudence of many states. Both the 1951 Convention and the ICCPR should be considered as living instruments that can address new situations that may arise some fifty years after they came into force even if there is certainly a risk in extending their scope to the situations for which a

47 B. Burson, Environmentally Induced Displacement and the 1951 Refugee Convention: Pathways to Recognition, [in:] T. Afifi, J. Jäger (eds.), 'Environment, Forced Migration and Social Vulnerability’, Springer-Verlag Berlin Heidelberg 2010, p. 13.

48 UNHCR, UNHCR, Environment\&Climate Change, Geneva 2015, note 10, p. 9; V. Türk, Discussion Forum on Climate Change, Berlin, 17.6.2014, https://www.refworld.org/ pdfid/53a3d9d64.pdf (accessed 28.3.2019).

49 H.J. von Doussa, A. Corkery, R. Chartres, Human Rights and Climate Change, Human Rights and Equal Opportunity Commission (HREOC) 2008, p. 22.

50 International Covenant on Civil and Political Rights, UN General Assembly Resolution 2200A (XXI), 16.12.1966, United Nations Treaty Series No. 14668, vol. 999, Article 7: 'No one shall be subjected to torture or to cruel, inhuman or degrading treatment or punishment. In particular, no one shall be subjected without his free consent to medical or scientific experimentation'.

51 G.S. Goodwin-Gill, J. McAdam, The Refugee in International Law, Oxford 2007, pp. 285, 305-309. 
solution is not within their regular ambit. Practice and observation provide ample evidence of possibilities for degrading treatment in situations where individuals are left destitute, without means of a livelihood in an environment that is uninhabitable because of the consequences of climate change. ${ }^{52}$

From time to time it can be observed how different states are trying to face this challenge in their national legislations. In 2007 a bill that called for a 'climate refugee' visa category was prepared in the Parliament of the Commonwealth of Australia. ${ }^{53}$

The idea of the aforementioned bill was to introduce to national legislation a class of visas to be known as climate change refugee visas. The criterion for a climate change refugee visa was that the applicant for the visa was a person who has been displaced as a result of a climate changeinduced environmental disaster. ${ }^{54}$

The bill attracted considerable criticism in the Senate of the Parliament of the Commonwealth of Australia and did not proceed to a vote. One of the questioned aspects of the bill was the legal validity of the concept given expression by the term 'climate refugee." 55

A lot of interesting reflections in this area are also provided by the judgments of the Immigration and Protection Tribunal of New Zealand. Between 2014 and 2017 the Tribunal considered four cases in which applicants for refugee status expressed concerns about the adverse effects of climate change on the Republic of Tuvalu, and in particular their consequences for life and of the limits imposed on the possibilities of obtaining livelihoods due to the rising sea level and related processes and environmental dangers. ${ }^{56}$

In all these cases, the Court considered that the applicants were not refugees within the meaning of the 1951 Convention. Finally, all four complaints were dismissed. The Supreme Court of New Zealand took a

52 In this context, it is also worth considering the application of legal instruments appropriate to regional human rights protection systems, such as article 3 ECHR.

53 Parliament of the Commonwealth of Australia, Migration (Climate Refugees) Amendment Bill 2007, C2007B00149, https://www.legislation.gov.au/Details/ C2007B00149 (accessed 28.3.2019).

54 Ibidem.

55 K. Koser, Environmental Change and Migration: Implications for Australia, Lowy Institute For International Policy, December 2012, pp. 9-10.

56 Immigration and Protection Tribunal New Zealand: NZIPT 800517-520, 4.6.2014; NZIPT 800859, 20.10.2015; NZIPT 801093-094, 23.2.2017, NZIPT 801120-123, 20.3.2017; https://www.justice.govt.nz (accessed 29.3.2019). 
similar decision in the case of citizen of the Republic of Kiribati, who applied for refugee status for himself and his family, for the same reasons as those of the citizens of Tuvalu referred to above. ${ }^{57}$

The first small breach in this rather clear case law of the New Zealand tribunals was the case of the Alesana family from Tuvalu. ${ }^{58}$ This case has not changed the way in which NewZealand tribunals adjudicate on similar matters. It did not cause a sudden recognition of the definition of 'environmental refugees' proposed by El-Hinnawi. It opened the field for further and more advanced discussions on the phenomenon of 'climate refugees' and the need to find legal solutions that meet the needs of citizens of countries affected by the consequences of climate change under the 1951 Convention.

Last but not least, it is worth mentioning the final ruling of the UN Human Rights Committee in the case of Teitiota v. New Zealand. ${ }^{59}$ It was the first decision in which the Committee recognized that people who flee the effects of climate change and natural disasters should not be returned to their country of origin if essential human rights would be at risk upon return. This is a significant decision with potentially far-reaching implications for the international protection of displaced people in the context of climate change and disasters. It also underscores the importance of states taking action to prevent or mitigate the consequences of climate change that in future could otherwise force people to leave, triggering international obligations. ${ }^{60}$

Committee expert Yuval Shany said that 'this ruling sets forth new standards that could facilitate the success of future climate change-related asylum claims'.61

57 Supreme Court of New Zealand, Teitiota v Ministry of Business Innovation and Employment [2015] NZSC 107, 20.7.2015, http://www.nzlii.org/nz/cases/NZSC/2015/107. html (accessed 29.3.2019).

58 Immigration and Protection Tribunal New Zealand, NZIPT 501370-371, 4.6.2014; https://forms.justice.govt.nz/search/Documents/IPTV2/Deportation/ rem_20140604_501370.pdf (accessed 29.3.2018).

59 Ioane Teitiota v. New Zealand (advance unedited version), CCPR/C/127/D/ 2728/2016, UN Human Rights Committee (HRC), 7.01.2020, https://www.refworld. org/cases,HRC,5e26f7134.html (accessed 29.5.2020).

60 UN Human Rights Committee decision on climate change is a wake-up call, according to UNHCR, https://www.unhcr.org/news/briefing/2020/1/5e2ab8ae4/un-human-rightscommittee-decision-climate-change-wake-up-call-according.html (accessed 29.5.2020).

61 Historic UN Human Rights case opens door to climate change asylum claims, https:// www.ohchr.org/en/NewsEvents/Pages/DisplayNews.aspx?NewsID=25482\&LangID=E (accessed 29.5.2020). 
If we are thinking of New Zealand in this context, it is impossible not to notice that this state could become the world's first country to recognize, in essence, climate change as an official reason to seek asylum. ${ }^{62}$

\section{Conclusion}

Despite the many differences between experts and scientists regarding the causes and consequences of this phenomenon, climate change is a fact. Regardless of whether we determine that they are caused by human activity or natural processes, the effects of the so-called climate change are objective in nature.

However, until today there has been no coordinated response from the international community to address the situation of populations displaced due to the impacts of climate change, which leaves the decision to accept them to the goodwill of individual states. Despite everything, mentioned causes show clearly willingness for discussion about possibilities of applying the 1951 Convention for the protection of climate refugees. Nevertheless, there is clear evidence of a willingness to discuss the possibility of applying the 1951 Convention to the protection of climate refugees.

Critics of the 1951 Convention usually group around two thought patterns. The first is promoted by those who think that the treaty is too old to respond to the challenges of resettlement in the $21^{\text {st }}$ century, such as climate change and natural disasters. The defenders of the second are those who think that the 1951 Convention is too generous and in part responsible for the large number of refugees that we currently notice around the world. It is not possible for the 1951 Convention to be too narrow and too wide at the same time, to use it to block and to facilitate access to protection at the same time.

62 J. Steffens, Climate Change Refugees in the Time of Sinking Islands, 'Vanderbilt Journal of Transnational Law' 2019, vol. 52, no. 3, p. 748; R. Noack, A New Zealand visa could trigger the era of 'climate change refugees', https://www.smh.com.au/world/a-newzealand-visa-could-trigger-the-era-of-climate-change-refugees-20171101-gzchd7.html (accessed 29.5.2020) 
Of course, it is possible to question whether and why it is necessary to apply the 1951 Convention to climate change refugees if they can be protected under core human rights treaties. ${ }^{63}$

The question is somewhat analogous to asking a doctor to explain why trying to save the life of a terminally ill patient means looking for the most effective medicine. The main subject of protection in the area under discussion is the central good of man, his personal dignity, therefore attempts to find effective protective mechanisms in the 1951 Convention should be no surprise.

Regardless of these doubts, the 1951 Convention remains to this day the most comprehensive regulation in the field of international human rights law, which defines the rights and obligations of refugees. In all fairness, it should be noted that the 1951 Convention neither protects all internally displaced persons nor has it been appointed to function as such.

In my opinion, adaptation of the 1951 Convention to the challenges facing the international community in connection with climate change will in itself become an expression of its responsibility for the consequences of these changes and their impact on individuals and entire communities.

\section{Bibliography}

1. Afifi T., Jäger J. (eds.), Environment, Forced Migration and Social Vulnerability, Springer-Verlag Berlin Heidelberg 2010

2. Black R., Environmental refugees: myth or reality?, New Issues in Refugee Research, Working Paper 34, UNHCR, Geneva 2001

3. Caney S., Climate change, human rights and moral thresholds, [in:] Stephen Humphreys (ed.), 'Human Rights and Climate Change', Cambridge University Press 2010

4. Cardy F., Environment and forced migration. A review, Nairobi 1994

5. Cummings B., Refugees of the 21st Century: Climate Change and an Uninhabitable Middle East/North Africa, 'University of Denver Water Law Review' 2019, vol. 22, no. 2

6. Gleick P.H., Water, Drought, Climate Change, and Conflict in Syria, 'Weather, Climate, and Society' 2014, vol. 6, no. 3

7. Goodwin-Gill G.S., McAdam J., The Refugee in International Law, Oxford, 2007

63 Convention against Torture and Other Cruel, Inhuman or Degrading Treatment or Punishment, New York, 10.12.1984, Article 3, United Nations Treaty Series , vol. 1465, p. 85. 
8. Hey E., Advanced Introduction to International Environmental Law, Elgar Publishing 2016

9. Kälin W., Schrepfer N., Protecting People Crossing Borders in the Context of Climate Change: Normative Gaps and Possible Approaches, UNHCR, Geneva 2012

10. Koser K., Environmental Change and Migration: Implications for Australia, Lowy Institute For International Policy, December 2012

11. Magniny V., Les réfugiés de l'environnement : hypothèse juridique à propos d'une menace écologique, Thèse pour le doctorat en droit présentée et soutenue publiquement le 25 Mai 1999, Paris 1999

12. McAdam J., Climate Change, Forced Migration, and International Law, OxfordNew York 2012

13. McAdam J., Climate Change-related Displacement of Persons [in:] 'The Oxford Handbook of International Climate Change', Oxford University Press 2016

14. McAdam J., The European Union Qualification Directive: The Creation of a Subsidiary Protection Regime, 'International Journal of Refugee Law' 2005, vol. 17, no. 3

15. Oliver-Smith A., Debating Environmental Migration: Society, Nature and Population Displacement in Climate Change, 'Journal of International Development' 2012, vol. 24

16. Osóbka P., The Problem of 'Climate Refugees' in the Perspective of International Humanitarian Law - Selected Issues, 'Studia z zakresu nauk prawnoustrojowych. Miscellanea’, vol. 2, no. VIII, Bydgoszcz 2018

17. Piguet E., Climate change and forced migration, New Issues in Refugee Research, Working Paper 2008, no. 153

18. Selby J., Dahi O. S., Fröhlich Ch., Hulme M., Climate change and the Syrian civil war revisited, 'Political Geography' 2017, vol. 60

19. Solomon M.K., Warner K., Protection of Persons Displaced as Results of Climate Change. Existing Tools and Emerging Frameworks, [in:] Gerrard M.B., Warnier G.E. (ed.), 'Threatened Island Nations', Cambridge University Press 2013

20. Stapleton S.O., Nadin R., Watson Ch., Kellett J., Climate change, migration and displacement: the need for a risk-informed and coherent approach, Overseas Development Institute and United Nations Development Programme 2017

21. Steffens J., Climate Change Refugees in the Time of Sinking Islands, 'Vanderbilt Journal of Transnational Law' 2019, vol. 52, no. 3

22. Termiński B., Migracje, uchodźstwo i wysiedlenia wewnętrzne w świecie doby globalizacji: studium socjologiczno-prawne, Regensburg 2016

23. UNHCR, Environment \& Climate Change, Geneva 2015

24. Verschuuren J., Research Handbook on Climate Change Adaptation Law, Elgar Publishing 2013

25. von Doussa H.J., Corkery A., Chartres R., Human Rights and Climate Change, Human Rights and Equal Opportunity Commission (HREOC) 2008 